\title{
Study of cyp2E1 Gene RsaI/PstI Polymorphisms in Patients with Gastric Cancer in North of Iran
}

\author{
Samaneh Kamalipour ${ }^{1}$, Ali Barzegar ${ }^{1}$, Novin Nikbakhsh ${ }^{2 *}$, Mohammad Shokrzadeh ${ }^{3}$ \\ ${ }^{1}$ Department of Basic Sciences, Sari Agricultural Sciences and Natural Resources University, Sari-Iran. \\ ${ }^{2}$ Department of Surgery, School of Medicine, Babol University of Medical Sciences, Babol-Iran. \\ ${ }^{3}$ Department of Toxicology, Faculty of Medicine, Mazandaran University of Medical Sciences, Sari-Iran.
}

Received: 19 Aug 2016

Revised : 14 Sep 2016

Accepted: 8 Oct 2016

Corresponding Author: Ali Barzegar

Department of Basic Sciences, Sari Agricultural Sciences and Natural

Resources University, Sari-Iran.

Phone: +981133822574

E-mail: alibar647@yahoo.com

\begin{abstract}
Background: North of Iran is amongst high incidence rate areas of gastric carcinoma where environmental carcinogenic compounds especially agricultural pesticides are massively used. Cytochrome P450 2E1 (CYP2E1) enzyme metabolically activates a large number of low molecular mass xenobiotics. The polymorphic nature of cyp2E1 gene control elements is associated with interindividual differences for toxicity of its substrates and may be responsible for increased gastric cancer susceptibility. The current study investigated the allelic frequencies of cyp2E1 gene RsaI/PstI polymorphisms and its association with gastric cancer risk in north of Iran.

Materials and Methods: This case-control study comprised of 120 gastric cancer patients and a group of 135 healthy individuals as control. Genotyping of cyp2E1 gene PstI/RsaI polymorphisms were carried out by PCR-RFLP method. Statistical analyzes were performed by Logistic regression model and $\mathrm{P}<0.05$ was considered as significance level.

Results: TNM classification showed that most patients (88\%) were in advanced stages when the disease was diagnosed. Frequencies of $\mathrm{C} 1 \mathrm{C} 1$ and $\mathrm{C} 1 \mathrm{C} 2$ genotypes of PstI/RsaI polymorphisms were 96 and $4 \%$ in case, and 99 and $1 \%$ in control group, respectively whereas homozygote $\mathrm{C} 2 \mathrm{C} 2$ genotype was not observed in any of the subjects. In Logistic regression model no significant association was found between RsaI/PstI allelic variants and gastric cancer risk $(\mathrm{p}=0.443, \mathrm{OR}=0.386$, $\mathrm{CI}=0.034-4.395$ ). Furthermore, no significant correlation was seen between genotypic frequencies and clinicopathological characteristics.

Conclusion: No significant association was found between cyp2E1 gene PstI/RsaI allelic variants and gastric cancer risk or clinicopathological characteristics of gastric cancer patients in north of Iran.
\end{abstract}

Keywords: CYP2E1 gene; Gastric Cancer; PstI/RsaI polymorphism; North of Iran

Please cite this article as: Kamalipour S, Barzegar A, Nikbakhsh N, Shokrzadeh M. Study of cyp2E1 gene RsaI/PstI polymorphisms in patients with gastric cancer in north of Iran. Res Mol Med. 2016; 4 (4): 22-27

\section{Introduction}

Gastric cancer is the fourth most frequent cancer, accounting for $8 \%$ of the total cancer cases, and the second leading cause of cancer related death resulting in $10.4 \%$ annual deaths worldwide $(1,2)$. Although the incidence rate of gastric cancer has decreased in the western world, its incidence and mortality have increased or remained stable in developing countries. Accordingly, in Iranian males and females it is the leading and the third cause of cancer related death, respectively $(3,4)$. Northern parts of Iran along with Northwestern regions are the highest risk areas for gastric cancer with an age-standardized incidence rate (ASR) of 49.1 for males and 25.4 for females (4). Gastric cancer mostly occurs as a result of complex interaction between genetic factors such as single nucleotide polymorphism (SNP) within key genes, 
and environmental risk factors such as Helicobacter pylori (H. pylori) colonization and exposure to diverse carcinogens $(5,6)$. Pesticides are among the most carcinogenic compounds that are massively used in north of Iran to protect agricultural products (7). Most exogenous (xenobiotics) and endogenous chemical carcinogens undergo biotransformation by phases I and II enzyme systems to activate and subsequently detoxify in the human body $(8,9,10$, 11). Genetic variation of the metabolizing enzymes may affect its activity or inducibility leading to individual differences in susceptibility to chemical carcinogen (12-14). Cytochrome P450 (CYP) is a superfamily of hemoproteins and a major kind of phase I enzymes detoxification that play a central role in the metabolism of many xenobiotics and endogenous compounds. It is also involved in activation of many carcinogens (15-16). CYP2E1, a member of the cytochrome P450 superfamily is an alcohol-inducible enzyme that plays a key role in the metabolic activation of many low molecular weight compounds such as benzene, vinyl chloride and $\mathrm{N}$ nitrosamines (17-19). It is located on chromosome $10 \mathrm{q} 26.3$ as an $11.7 \mathrm{~kb}$ gene consisting of 9 exons and 8 introns that encodes for a 493 amino acid protein (20). Some functional cyp2E1 gene SNPs have been identified that alter the transcriptional activity of the gene and as a result influences the susceptibility to develop cancer (21). Since the coding region of the human cyp2E1 gene is highly conserved, it is likely that the variability is related to polymorphic sites at the control elements present in the upstream region (22). RsaI/PstI polymorphisms in the 5'-flanking region are composed of two point mutations including RsaI polymorphism at $-1053 \mathrm{C}>\mathrm{T}(\mathrm{ra2031920})$ and PstI at $-1293 \mathrm{G}>\mathrm{C}$ (rs3813867) $(22,23)$. They are in complete linkage disequilibrium resulting in three genotypes; the individuals with predominant homozygous allele $(\mathrm{C} 1 / \mathrm{C} 1)$, the heterozygous allele $(\mathrm{C} 1 / \mathrm{C} 2)$, and the rare homozygous allele $(\mathrm{C} 2 / \mathrm{C} 2)$ of PstI/RsaI polymorphisms are named the wild-type homozygote, the heterozygote, and the rare homozygote, respectively. These polymorphisms are reported to alter transcriptional activity of the cyp2E1 gene and their association with greater risk for oral, pharyngeal, liver, lung and gastric cancers have been documented in numerous studies. Nevertheless, several studies conducted on the possible association of cyp2E1 RsaI/PstI genetic variants and gastric cancer risk produced controversial results. High incidence rate of gastric cancer in north of Iran where pesticides are being massively used and different toxicity of chemical carcinogens in relation to metabolizing enzymes variants has prompted us to analyze interindividual variation of cyp2E1 Rsa1/Pst1 polymorphisms as a key enzyme for xenobiotics metabolism. So, the aim of this research was to study the genotypic frequency of cyp2E1 gene Rsa1/Pst1 polymorphisms and its association with the risk of gastric cancer in north of Iran.

\section{Materials and methods}

Study population

The present population based case-control study comprised of 120 gastric cancer patients who were diagnosed and underwent surgery in Ayatollah Rowhani and Shahid Beheshti hospitals in Mazandaran and Sayyad Shirazi Hospital in Golestan province during 2011 to 2013. A group of 135 healthy individuals randomly selected from blood donor volunteers without any familial history of the disease were also enrolled as control for statistical analysis. The healthy controls were age-and sexmatched and were from the same ethnic group. Five $\mathrm{ml}$ samples of peripheral blood were collected form each case and control subjects in tubes containing EDTA and stored at $-20{ }^{\circ} \mathrm{C}$. Demographic (e.g. age, sex) and clinicopathological (e.g. TNM stage) characteristics of the subjects were extracted from their medical records and histopathological reports.

\begin{tabular}{|c|c|}
\hline Clinicopathological Variables & Number of patients (\%) \\
\hline \multicolumn{2}{|l|}{ Age } \\
\hline$\leq 40$ & $10(9)$ \\
\hline$>40$ & 104(91) \\
\hline \multicolumn{2}{|l|}{ Type of cancer } \\
\hline Cardia & $10(14)$ \\
\hline Non-cardia & $60(86)$ \\
\hline \multicolumn{2}{|l|}{ TNM staging } \\
\hline I- II & $12(12)$ \\
\hline III - IV & $86(88)$ \\
\hline \multicolumn{2}{|l|}{ Family history } \\
\hline Positive & $23(21)$ \\
\hline Negative & $87(79)$ \\
\hline \multicolumn{2}{|l|}{ Smoking } \\
\hline Positive & $35(33)$ \\
\hline Negative & $72(67)$ \\
\hline
\end{tabular}

\section{DNA extraction}

Genomic DNA was extracted from whole blood cells by routine phenol-chloroform method. DNA concentration of each sample was measured by UV spectrophotometry and its purity was examined through agarose gel electrophoresis. DNA samples were stored at $-20{ }^{\circ} \mathrm{C}$ for future use.

cyp2E1 RsaI/PstI polymorphisms analysis Genotyping of both Pst1 and Rsa1 polymorphic sites were determined by polymerase chain reaction restriction fragment length polymorphism (PCR- 
RFLP) method. A set of forward 5'-CATTGTCAGT TCTCACCTCG-3' and reverse 5'-GCTCCACATTG ACTAGCTTC-3' primers were designed using a cyp2E1 gene sequence (accession number: NG00838 3.1) available in GenBank which amplify a 537 bp fragment from nucleotide position -1392 to -855 encompassing both variable alleles. Amplification was carried out in a $25 \mu \mathrm{l}$ mixture containing $1 \mathrm{X}$ PCR buffer, $120 \mathrm{ng}$ of genomic DNA, $1.5 \mathrm{mM}$ of $\mathrm{MgCl} 2$, $200 \mu \mathrm{M}$ of each dNTP, 0.3 PM of each forward and reverse primers and $2 \mathrm{U}$ of taq DNA polymerase $(10 \mathrm{U} / \mu \mathrm{l})$. PCR cycling conditions consisted of one cycle initial denaturation at $95{ }^{\circ} \mathrm{C}$ for $4 \mathrm{~min}, 35$ cycles including denaturation at $94{ }^{\circ} \mathrm{C}$ for $40 \mathrm{~s}$, annealing at $46^{\circ} \mathrm{C}$ for $30 \mathrm{~s}$, and extension at $72{ }^{\circ} \mathrm{C}$ for $30 \mathrm{~s}$ and one cycle final extension at $72{ }^{\circ} \mathrm{C}$ for $7 \mathrm{~min}$. Amplified products were electrophoresed in $1.5 \%$ agarose gel and visualized following staining with ethidium bromide. Concentration of amplified fragments was measured using spectrophotometry technique to apply equal amounts of each sample for restriction digestion. Allelic variants of both polymorphic sites were studied through restriction digestion with RsaI and PstI restriction enzymes to evaluate if they were at linkage disequilibrium as other genotypes. Digestion reaction was performed in a $25 \mu \mathrm{l}$ mixture containing $1 \mathrm{X}$ Tango buffer, 200ng amplified fragment, and $2 \mathrm{U}$ RsaI $(10 \mathrm{U} / \mu \mathrm{l})$ restriction enzyme for RsaI polymorphism and $1 \mathrm{X} \mathrm{O}$ buffer, 200ng amplified fragment, and 2U PstI restriction enzyme $(10 \mathrm{U} / \mu \mathrm{l})$ for PstI polymorphism. Reaction mixture was incubated at $37^{\circ} \mathrm{C}$ for 4 hours and the products were analyzed through electrophoresis at $2.5 \%$ agarose gel. Following digestion with RsaI restriction enzyme, homozygote $\mathrm{CC}$ genotype produces two 339 and 198 bp fragments, homozygote mutant TT genotype produces a single $537 \mathrm{bp}$ fragment and heterozygote CT genotype produces three 537, 339 and 198 bp fragments. In case of PstI polymorphism GG genotype produces a single $537 \mathrm{bp}$ fragment, CC genotype produces two 432 and $105 \mathrm{bp}$ fragments and heterozygote GC genotype produces three 537, 432 and 105bp fragments. At least one sample of each unique restricted pattern was sequenced in both directions at Bioneer company (Korea) to verify the results of RFLP genotyping.

\section{Ethics Statement}

All patients and healthy controls provided their verbal informed consent to participate in this study.

\section{Statistical analysis}

All Statistical analyzes were performed in SAS 9.1 statistics software and $\mathrm{P}<0.05$ was considered as statistical significance level. The genotype and allele frequencies of cyp2E1 RsaI/PstI polymorphisms were tested for Hardy-Weinberg equilibrium (HWE) using $\chi 2$ test. The distribution of cyp2E1 RsaI/PstI polymorphisms between case and control groups were calculated using unconditional Logistic regression methods and Odds ratio (OR), confidence intervals (CI), and p-values adjusted for age were measured to study the association between genotypes and the risk of gastric cancer or some clinicopathological data (20).

\section{Results}

Demographic and clinicopathological data

This study was performed in 120 gastric cancer patients including $96(80 \%)$ males and 24 (20\%) females with an average age of $65.7 \pm 8.16$ years (Table 1). The control group composed of 97 (72\%) men and $38(28 \%)$ women with the mean age of $62.5 \pm 6.472$ years. The Student's t test showed no significant differences in matching characteristics between cases and controls $(p>0.1311)$. Thirty five out of 107 patients (33\%) were smokers while this rate was $23 \%$ for the controls. So, significant association was found between smoking and disease incidence $(\mathrm{P}=0.02)$. Results of Chi-square test showed that the genotype frequency of case and control groups did not significantly diverge from HWE (both $\mathrm{p}>0.05$ ). Pathological assays showed that most patients $(88 \%)$ were in stages III and IV when the disease was diagnosed for the first time.

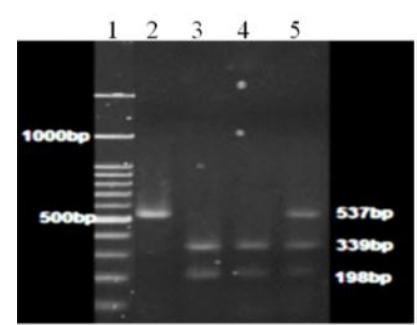

(A)

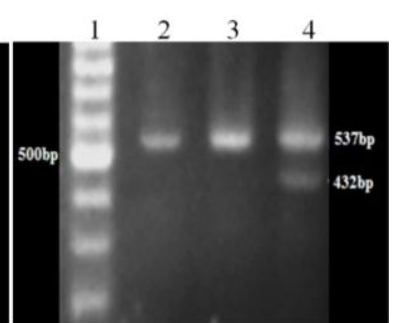

(B)
Figure 1. PCR-RFLP profile of CYP2E1 gene RsaI/PstI allelic variants in $2.5 \%$ agarose gel. A) RsaI RFLP: 1: 100bp ladder, 2: Amplified fragment (537bp), 3, 4: Homozygous wild type (339 and 198bp), 5: Heterozygous genotype (537, 339 and 198bp). B) PstI RFLP: 1: 100 bp ladder, 2, 3: Homozygous wild type (537bp), 4: Heterozygous genotype (537, 432 and 105bp).

The cyp2E1 gene RsaI/PstI genotype distribution and its association to clinicopathological characteristics The allelic variants of cyp2E1 gene Rsa1/Pst1 polymorphisms were determined according to the patterns created following digestion of amplified fragments by respective restriction enzyme (Figure 1) and resulting genotypic distributions in cases and controls are shown in table 2. Results of RsaI polymorphism analysis showed that the genotypic frequencies of $\mathrm{C} 1 \mathrm{C} 1$ and $\mathrm{C} 1 \mathrm{C} 2$ genotypes were 96 and $4 \%$ in case, and 98.5 and $1.5 \%$ in control group, 
respectively whereas homozygote $\mathrm{C} 2 \mathrm{C} 2$ genotype was not observed in any subjects. Similar genotypic distribution was found on PstI digestion of amplified fragments in cases and controls verifying complete linkage disequilibrium of these two polymorphisms.

Table 2. Distribution of cyp2E1 gene RsaI/PstI polymorphisms and gastric cancer risk.

\begin{tabular}{|c|c|c|c|c|c|c|c|c|}
\hline \multirow{2}{*}{\multicolumn{2}{|c|}{ Polymorphisms }} & \multicolumn{2}{|c|}{ Number } & \multicolumn{2}{|c|}{ Non-adjusted $^{a}$} & \multicolumn{3}{|c|}{ Adjusted $^{b}$} \\
\hline & & $\operatorname{Cases}(n=120)$ & Controls $(n=135)$ & $\mathrm{P}$ value & OR & $\mathrm{P}$ value & OR & CI (95\%) \\
\hline \multirow{2}{*}{ RsaI/PstI } & $\mathrm{C} 1 \mathrm{C} 2$ & $5(4 \%)$ & $2(1.5 \%)$ & $\cdots$ & 1.00 & $\cdots$ & 1.00 & \\
\hline & $\mathrm{C} 1 \mathrm{C} 1$ & $115(96 \%)$ & $133(98.5 \%)$ & 0.346 & 0.312 & 0.443 & 0.386 & $0.034-4.395$ \\
\hline
\end{tabular}

$\mathrm{OR}=$ Odd Ratio, $\mathrm{CI}=$ Confidence Intervals, ${ }^{\mathrm{a}}$ Logistic regression model, non-adjusted, ${ }^{\mathrm{b}}$ Logistic regression model, adjusted for diagnostic age.

In the logistic regression model no significant association was seen between RsaI/PstI allelic variants and gastric cancer risk ( $\mathrm{p}$ value $=0.443$,
$\mathrm{OR}=0.386, \quad \mathrm{CI}=0.034-4.395) . \quad$ The association between RsaI/PstI genotypes and clinicopathological characteristics was analyzed and presented in table 3 .

Table 3. Relationship between cyp2E1 RsaI/PstI polymorphisms and known clinicopathological variables.

\begin{tabular}{|c|c|c|c|c|c|}
\hline \multirow{2}{*}{ Clinicopathological Variables } & \multirow{2}{*}{ Number $(\%)$} & \multicolumn{2}{|c|}{ Genotype } & \multicolumn{2}{|c|}{ Adjusted $^{\mathrm{a}}$} \\
\hline & & C1C1 & $\mathrm{C1C2}$ & p value & OR \\
\hline $\begin{array}{l}\text { Age } \\
\leq 40 \\
>40\end{array}$ & $\begin{array}{l}10(9) \\
104(91)\end{array}$ & $\begin{array}{l}10(100) \\
99(95)\end{array}$ & $\begin{array}{l}0(0) \\
5(5)\end{array}$ & $\begin{array}{l}\ldots \\
1.00\end{array}$ & $\begin{array}{l}1.00 \\
1.00\end{array}$ \\
\hline $\begin{array}{l}\text { Type of cancer } \\
\text { Cardia } \\
\text { Non-cardia }\end{array}$ & $\begin{array}{l}10(14) \\
60(86)\end{array}$ & $\begin{array}{l}10(100) \\
55(92)\end{array}$ & $\begin{array}{l}0(0) \\
5(8)\end{array}$ & $\begin{array}{l}\ldots \\
0.971\end{array}$ & $\begin{array}{l}1.00 \\
<0.001\end{array}$ \\
\hline $\begin{array}{l}\text { TNM staging } \\
\text { I- II } \\
\text { III - IV }\end{array}$ & $\begin{array}{l}12(12) \\
86(88)\end{array}$ & $\begin{array}{l}12(100) \\
81(94)\end{array}$ & $\begin{array}{l}0(0) \\
5(6)\end{array}$ & $\begin{array}{l}\ldots \\
0.982\end{array}$ & $\begin{array}{l}1.00 \\
<0.001\end{array}$ \\
\hline $\begin{array}{l}\text { Family history } \\
\text { Positive } \\
\text { Negative }\end{array}$ & $\begin{array}{l}23(21) \\
87(79)\end{array}$ & $\begin{array}{l}20(89) \\
84(97)\end{array}$ & $\begin{array}{l}3(11) \\
3(3)\end{array}$ & $\begin{array}{l}\ldots \\
0.311\end{array}$ & $\begin{array}{l}1.00 \\
4.962\end{array}$ \\
\hline $\begin{array}{l}\text { Smoking habit } \\
\text { Positive } \\
\text { Negative }\end{array}$ & $\begin{array}{l}35(33) \\
72(67)\end{array}$ & $\begin{array}{l}33(94) \\
69(96)\end{array}$ & $\begin{array}{l}2(6) \\
3(4)\end{array}$ & $\begin{array}{l}\ldots \\
0.595\end{array}$ & $\begin{array}{l}1.00 \\
2.167\end{array}$ \\
\hline
\end{tabular}

\footnotetext{
${ }^{a}$ Logistic regression model adjusted for diagnostic age. All statistical tests were two-sided with a significance level of $\mathrm{p}<0.05$
}

The results showed that none $\mathrm{C} 1 \mathrm{C} 1$ and $\mathrm{C} 1 \mathrm{C} 2$ genotypes were significantly correlated with demographic and clinicopathological characteristics including age at diagnosis $(\mathrm{p}=1.00)$, type of cancer $(\mathrm{p}=0.971)$, stage of disease $(\mathrm{p}=0.982)$, smoking habit $(\mathrm{p}=0.595)$ and family history $(\mathrm{p}=0.311)($ Table 3$)$.

\section{Discussion}

In spite of decrease in the incidence rate of gastric cancer in western world, the North and northwest of Iran are still amongst high incidence rate areas of gastric carcinoma $(24,25)$. Cytochrome P450 2E1 (CYP2E1) enzyme metabolically activates a large number of low molecular mass xenobiotics and the polymorphic nature of the controlling elements of its gene is associated with interindividual differences for toxicity of its substrates and cancer risk $(26,27,28)$. We investigated allelic frequency of cyp2E1 RsaI/PstI polymorphisms at the $5^{\prime}$ flanking region and its association with gastric cancer risk in north of Iran.
The average age of patients was $65.7 \pm 8.16$ years and most patients $(80 \%)$ were males that is consistent with the results of other epidemiological researches in Iran (Table 1) $(29,30)$. The positive association between tobacco smoking and gastric cancer risk is also confirmed in this study $(\mathrm{p}=0.02)$. Pathological analysis showed that only $14 \%$ of patients had tumors in cardia region. This is in contrary with some other epidemiological studies documenting cardia as the major part for gastric cancer in north and northwest of Iran (4). TNM classification showed that $88 \%$ of patients were diagnosed in advanced stages of the disease (III and IV). Clinically, symptoms of gastric cancer tend to emerge late in the development of the disease $(4,31)$. So, regular periodic tests and public education about the early warning signs and diagnosis of the disease are necessary (31). The cyp2E1 gene $\mathrm{C} 1 / \mathrm{C} 1$ and $\mathrm{C} 1 / \mathrm{C} 2$ genotypes distribution of RsaI/PstI polymorphisms were $97.5 \%$ and $2.5 \%$ in case and control groups, respectively. 
Interestingly, the mutant $\mathrm{C} 2 / \mathrm{C} 2$ genotype was not detected in any samples of the cases and controls. Striking inter-ethnic differences were found between different races with respect to cyp2E1 RsaI/PstI polymorphisms. Studies of RsaI/PstI polymorphisms in Caucasian and Asian population showed that the frequency of mutant $\mathrm{C} 2 / \mathrm{C} 2$ genotype was $6 \%$ and $0.1 \%$ while the heterozygote genotype was found in $37 \%$ and $5 \%$, respectively $(32,33)$. In this research, logistic regression model showed no significant association between RasI/PstI polymorphism and gastric cancer risk $(\mathrm{p}=0.443, \mathrm{OR}=0.386, \mathrm{CI}=0.034$ 4.395). Furthermore, no significant correlation was detected between RsaI/PstI genotypes and demographic or clinicopathological characteristics. Previous researches on the association between cyp2E1 polymorphisms and gastric cancer risk has yielded conflicting results. Study of genotypic frequencies of CYP2E1 PstI/RsaI polymorphism in Chinese patients and a small Costa Rican population paradoxically demonstrated significant correlation; despite positive association of $\mathrm{C} 2$ allele with gastric cancer incidence in Chinese population, it was found that $\mathrm{C} 2 \mathrm{C} 2$ genotype was associated with reduced risk of gastric cancer in Costa Rican population $(32,34)$. However, meta-analyses based on 24 case-control studies and a study on Japanese population revealed no significant associations between CYP2E1 RsaI/PstI polymorphism and gastric cancer risk (35, 36). In addition to inter-ethnic differences of cyp2E1 gene and their discrete effects on cancer susceptibility, the interaction of genetic and environmental risk factors may be involved in cancer development (37). Organophosphorus pesticides are amongst the most important environmental carcinogenic compounds which are massively used in north of Iran (7). We recently detected Diazinone pesticide in the blood serum of some gastric cancer patients (0.155 ppm) using GC-mass analysis (unpublished data). So, it is suggested that the influences of both genetic and environmental risk factors should be considered simultaneously on gastric cancer incidence. Particularly, the possible epigenetic effects of prevalent pesticides should be studied on cyp2E1 gene expression. Furthermore, due to low frequencies of heterozygote $\mathrm{C} 1 \mathrm{C} 2$ and mutant $\mathrm{C} 2 \mathrm{C} 2$ genotypes of RsaI/PstI polymorphisms researches with larger groups are needed to verify these points.

\section{Acknowledgments}

We appreciate Dr Safaaee and also the staffs of surgery division of Ayatollah Rouhani, Shahid Beheshti and Sayad Shirazi hospitals for their kind collaboration for sample preparation.

\section{Authors' contributions}

$\mathrm{AB}$ and SK participated in the whole processes of the study including design of research work, data analysis and drafting manuscript. NN performed surgery and provided samples. MSh helped in providing some materials and equipment.

\section{Conflict of interest}

The authors declare that they have no conflict of interest in this work.

\section{Support/Funding}

This project is partly supported by a grant from Sari Agricultural Sciences and Natural Resources University

\section{References}

1. Lao S, Caldas C, Fitzgerald R. Genetic predisposition to gastroesophageal cancer. Curr Opin Genet Dev. 2010; 20(3): 210-217 PMID: 20347291

2. Siegel RL, Miller KD, Jemal A. Cancer Statistics, CA Cancer J Clin 2016; 66(1):7-30. PMID: 26742998

3. Mousavi SM, Gouya MM, Ramazani R, et al. Cancer incidence and mortality in Iran. Ann Oncol. 2009; 20(3):556-63. PMID: 19073863

4. Malekzadeh R, Derakhshan MH, Malekzadeh Z. Gastric cancer in Iran: epidemiology and risk factors. Arch Iran Med 2009; 12(6):576-583. PMID: 19877751

5. Correa P. Human gastric carcinogenesis: A multistep and multifactorial process-first American Cancer Society award lecture on cancer epidemiology and prevention. Cancer Res. 1992; 52(24):6735-40. PMID: 1458460

6. Shikata K, Doi Y, Yonemoto K, et al. Population-based prospective study of the combined influence of cigarette smoking and Helicobacter pylori infection on gastric cancer incidence the Hisayama study. Am J Epidemiol. 2008; 168(12):1409-15. PMID: 18945691

7. Shokrzadeh M, Karami M, Ghadi MAE. Measuring organophosphorus insecticide residue in rice produced in Amol, north of Iran. J Mazandaran Univ Med Sci. 2013; 23(1): 215-21

8. Slattery ML, Edwards SL, Samowitz W, Potter J. Associations between family history of cancer and genes coding for metabolizing enzymes (United States). Cancer Causes Control 2000; 11(9):799-803. PMID: 11075868

9. Kim JW, Lee CG, Park YG, et al. Combined analysis of germline polymorphisms of p53, GSTM1, GSTT1, CYP1A1, and CYP2E1. Cancer 2000; 88(9):2082-91. PMID: 10813720

10. Tan XL, Spivack SD. Dietary chemoprevention strategies for induction of phase II xenobiotic-metabolizing enzymes in lung carcinogenesis: a review. Lung Cancer 2009; 65(2):129-37. PMID: 19185948

11. Nebert DW, Dalton TP. The role of cytochrome P450 enzymes in endogenous signaling pathways and environmental carcinogenesis. Nat Rev Cancer. 2006; 6(12):947-60. PMID: 17128211 
12. Boccia S, Sayed-Tabatabaei FA, Persiani R, et al Polymorphisms in metabolic genes, their combination and interaction with tobacco smoke and alcohol consumption and risk of gastric cancer: a case-control study in an Italian population. Bio Med Cancer. 2007; 7(1):206

13. Gonzalez FJ, Kimura S. Understanding the role of xenobiotic metabolism in chemical carcinogenesis using gene knockout mice. Mutat Res. 2001; 477(1-2):79-87. PMID: 11376689

14. Cai L, Yu SZ, Zhan Z. Cytochrome P450 2E1 genetic polymorphism and gastric cancer in Changle, Fujian Province. World J Gastroenterol. 2001; 7(6):792-5. PMID: 11854903

15. Guengerich FP. Roles of cytochrome P-450 enzymes in chemical carcinogenesis and cancer chemotherapy. Cancer Res. 1988; 48(11):2946-54. PMID: 3284639

16. Nair PC, McKinnon RA, Miners JO. Cytochrome P450 structure-function: insights from molecular dynamics simulations. Drug Metab Rev. 2016; 48(3):434-52. PMID: 27167388

17. Bartsch H, Montesano R. Relevance of nitrosamines to human cancer. Carcinogenesis. 1984; 5(11):1381-93. PMID: 6386215

18. Guengerich FP, Kim DH, Iwasaki M. Role of human cytochrome P-450IIE1 in the oxidation of many low molecular weight cancer suspects. Chem Res Toxicol. 1991; 4(2):168-79. PMID: 1664256

19. Lieber CS. Cytochrome P4502E1: its physiological and pathological role. Physiol Rev. 1997; 77(2):517-44. PMID: 9114822

20. Umeno M, McBride OW, Yang CS, Gelboin HV, Gonzalez FJ Human ethanol-inducible P450IIE1: complete gene sequence, promoter characterization, chromosome mapping, and cDNAdirected expression. Biochemistry. 1988; 27(25):9006-13. PMID: 3233219

21. Gao CM, Takezaki T, Wu JZ, et al. CYP2E1 Rsal polymorphism impacts on risk of colorectal cancer association with smoking and alcohol drinking. World J Gastroenterol. 2007; 13(43):5725-30. PMID: 17963298

22. Hayashi SI, Watanabe J, Kawajiri K. Genetic polymorphisms in the $5^{\prime}$-flanking region change transcriptional regulation of the human cytochrome P450IIE1 gene. J Biochem. 1991; 110(4):55965. PMID: 1778977

23. Morita M, Le Marchand L, Kono S, et al. Genetic polymorphisms of CYP2E1 and risk of colorectal cancer: The fukuoka colorectal cancer study. Cancer Epidemiol Biomarkers Prev. 2009; 18(1):235-41. PMID: 19124503

24. Jemal A, Bray F, Center MM, et al. Global cancer statistics. CA Cancer J Clin. 2011; 61(2):69-90. PMID: 21296855

25. Mohebbi M, Mahmoodi M, Wolfe R, et al. Geographical spread of gastrointestinal tract cancer incidence in the Caspian Sea region of Iran: spatial analysis of cancer registry data. BMC Cancer 2008; 8:137. PMID: 18479519
26. Glatt HR. Overview of bioactivation of chemical carcinogens. Biochem Soc Trans. 2000; 28(2):1-6. PMID: 10816089

27. Cai L, Zheng ZL, Zhang ZF. Cytochrome p450 2E1 polymorphisms and the risk of gastric cardia cancer. World $\mathrm{J}$ Gastroenterol. 2005; 11(12): 1867-71. PMID: 15793883

28. Tang K, Li X, Xing Q, et al. Genetic polymorphism analysis of cytochrome P4502E1 (CYP2E1) in Chinese Han populations from four different geographic areas of Mainland China. Genomics. 2010; 95(4):224-29. PMID: 20100563

29. Babaei M, Pourfarzi F, Yazdanbod A, et al. Gastric cancer in Ardabil, Iran-A review and update on cancer registry data. Asian Pac J Cancer Prev. 2010; 11(3): 595-9. PMID: 21039022

30. Ghorbani A, Hosseini V, Ajami A, et al. Association between polymorphism of interleukin 17 (IL-17F) and increased susceptibility to gastric cancer. J Mazandaran Univ Med Sci. 2012; 22(91): 11-20.

31. Biglarian A, Hajizadeh E, Govhari M, Khodabakhshi R. Survival analysis of patients with gastric cancer and its related factors. Kosar Med J 2008; 12(4): 345-355.

32. Feng J, Pan X, Yu J, et al. Functional PstI/RsaI polymorphism in CYP2E1 is associated with the development, progression and poor outcome of gastric cancer. PloS One. 2012; 7(9):e44478. PMID: 22957075

33. Bolt HM, Roos PH, Thier R. The cytochrome P-450 isoenzyme CYP2E1 in the biological processing of industrial chemicals: Consequences for occupational and environmental medicine. Int Arch Occup Environ Health. 2003; 76(3):174-185.

34. Gonzalez A, Ramirez V, Cuenca P, Sierra R. Polymorphisms in detoxification genes cyp1A1, cyp2E1, GSTT1 and GSTM1 in gastric cancer susceptibility. Rev Biol Trop. 2004; 52(3):591-600. PMID: 17361553

35. Kato S, Naito Z, Matsuda N, et al. Localization of cytochrome P4502E1 enzyme in normal and cancerous gastric mucosa and association with its genetic polymorphism in unoperated and remnant stomach. J Nippon Med Sch. 2011; 78:224-34. PMID: 21869556

36. Tsukino H, Kuroda Y, Qiu D, et al. Effects of cytochrome P450 (CYP) 2A6 gene deletion and CYP2E1 genotypes on gastric adenocarcinoma. Int J Cancer. 2002; 100:425-8. PMID: 12115524

37. Shahriary GM, Galehdari H, Jalali A, et al. CYP2E $1 * 5 B$, CYP2E1*6, CYP2E1*7B, CYP2E1*2, and CYP2E1*3 allele frequencies in Iranian populations. Asian Pac J Cancer Prev. 2012; 13(12):6505-10. PMID: 23464483 